\title{
Method for characterizing extracellular proteins from the cell wall proteome of the copper tolerant fungus Phialophora malorum
}

\author{
Geoffrey Daniel $^{\mathrm{a}, *}$, Jindrich Volc ${ }^{\mathrm{b}, 1}$, Petr Halada ${ }^{\mathrm{b}}$, Hasanthi Karunasekera ${ }^{\mathrm{a}}$, Jong Sik Kim ${ }^{\mathrm{c}}$ \\ ${ }^{a}$ Department of Forest Biomaterials and Technology/Wood Science, Swedish University of Agricultural Sciences, P.O. Box 7008, SE-750 07, Uppsala, Sweden \\ ${ }^{\mathrm{b}}$ Institute of Microbiology of the CAS, V. V. I, Vídeňská 1083, 142 20, Prague 4, Czech Republic \\ ${ }^{\mathrm{c}}$ Department of Wood Science and Engineering, Chonnam National University, Gwangju, 61186, Republic of Korea
}

\section{A R T I C L E I N F O}

\section{Keywords:}

Copper tolerance

Differential protein profiles

MALDI-TOF MS/MS

Peptide sequencing

Phialophora malorum

Soft rot decay

Cell wall proteome

\begin{abstract}
A B S T R A C T
Phialophora malorum is a well-known copper tolerant fungus causing soft rot decay of copper-treated wood inservice in ground contact situations worldwide. The aim of the present work was to develop a method that allowed studies of the mechanism(s) behind extracellular copper tolerance by examining the profile of proteins expressed by $P$. malorum in the cell wall/slime (subproteome) environment in mycelia grown in Cu-supplemented media. The study involves development of a novel non-destructive approach using mild extraction, concentration, separation (SDS-PAGE electrophoresis) and characterization (MALDI-TOF MS/MS) of the proteins present. Studies revealed differential protein profiles and expression in Cu-supplemented $\left(0.1 \% \mathrm{CuSO}_{4}\right)$ vs control shake cultures after 10 days growth. Twelve proteins including several hydrolytic (i.e. glucosidases, pectinase, polygalacturonase) enzymes were either unique or over-expressed in Cu-cultures compared to controls. The cell wall location of the proteins was consistent with a role in copper tolerance and detoxification by binding Cu-ions extracellularly. Several of the proteins (e.g. hydrolases, pectinase) are also involved in wood cell wall biomineralization. It is proposed that the concentration of metabolites (organic acids) slowly released in close vicinity of hyphal surfaces by weakly bound enzymes over-expressed through Cu-stress may function to reduce levels of free non-chelated $\mathrm{Cu}$ (II) ions entering the cell cytoplasm and therefore provide a first level of defense against copper toxicity.
\end{abstract}

\section{Introduction}

Fungi have developed a variety of mechanisms to tolerate toxic levels of heavy metals in their immediate environments (Gadd, 1993; Hall, 2002; Jacobs et al., 2016; Akgul and Akgul, 2018). A number of resistance systems have been advocated including: (i) the active efflux/ exclusion/excretion of accumulated metals from cells as described with some yeasts (e.g. Weissman et al., 2000; Ito et al., 2007), (ii) control of metal uptake by complexation at the cell wall with extracellular polymeric slime materials (EPS) (Daniel and Nilsson, 1989; Yahaya et al., 2009) or chelation/precipitation by soluble secreted metabolites (ElMeleigy, 1992) such as oxalic acid (Jarosz-Wilkołazka and Graz, 2006; Clausen et al., 2000; Clausen and Green, 2003; Green and Clausen, 2003), (iii) detoxification of accumulated metal ions by intracellular complexation/immobilization by binding to intracellular protein chelators like metallothioneins (e.g. Schwartz et al., 2013), and (iv) metal sequestration in the cellular periplasm or vacuoles (Pearce and Sherman, 1999). Typically, these mechanisms may function individually or in combination to prevent a fungus from heavy metal toxicity stress, their purpose being to reduce damage to biogenic macromolecules sensitive to oxidative species derived from reactive metal ions.

Fungi with an ability to degrade waterborne preservative treated wood (i.e. wood treated with metals like chromated-copper-arsenate (CCA), or copper treatments; Mantanis et al., 2014; Humar and Thaler, 2017) are recognized to have metal tolerance or possess mechanisms to prevent metal stress and death. Their ability to degrade metal-treated wood and at the same time tolerate heavy metals has generally been ascribed as giving such fungi a competitive advantage although this hypothesis has been questioned recently for soft rot fungi (Karunasekera et al., 2017). Previous studies on different Phialophora spp. causing soft rot on copper-treated wood have shown certain species

\footnotetext{
* Corresponding author.

E-mail addresses: geoffrey.daniel@slu.se (G. Daniel), halada@biomed.cas.cz (P. Halada), hasinidinven@gmail.com (H. Karunasekera), jongsik.kim@chonnam.ac.kr (J.S. Kim).

1 Deceased.
} 
(e.g. P. malorum and P. mutabilis) to grow in-vitro on media containing high copper concentrations (i.e. as $\mathrm{CuSO}_{4}$ or micronized copper) (Daniel and Nilsson, 1988; Karunasekera and Daniel, 2013) indicating strong Cu-tolerance. Earlier, electron microscopy and X-ray microanalytical studies have shown $P$. mutabilis to bind copper both intracellularly to cellular components and extracellularly to cell wall/ slime (subproteome) materials suggesting that a variety of mechanisms may be involved (Daniel and Nilsson, 1989). Phialophora malorum and $P$. mutabilis when grown in-vitro on $\mathrm{CuSO}_{4}$ supplemented media cause green discoloration of the culture fluid and bind copper to mycelia suggesting employment of an extracellular mechanism (i.e. external to cell membrane) for copper reduction possibly involving proteins or extracellular chelators (Daniel and Nilsson, 1988; Karunasekera et al., 2019). In a previous study, protein expression by $P$. malorum mycelia grown in $\mathrm{CuSO}_{4}$ media were examined using a global proteomic approach that showed a number of characteristic proteins up- or downregulated during growth in copper supplemented media (Karunasekera et al., 2019). The global approach however, involved analysis of the entire $P$. malorum proteome and while some information can be retrieved indirectly from the dataset on metabolic functions and likely cellular distribution, considerably less information is available for specific cellular structures and regions. For P. malorum this was complicated further as the genome is currently unknown (Karunasekera et al., 2019).

The aim of the present study was to develop a specific method to examine the profile of extracellular proteins (i.e. proteins weekly bound to the fungal cell wall/slime) differentially expressed in the cell wall proteome in $\mathrm{Cu}$-supplemented vs control in-vitro liquid cultures. Work included development of a non-destructive approach involving mild protein extraction, concentration, separation (via electrophoresis) and identification via sequencing of polypeptides (MALDI-TOF MS/MS). Phialophora spp. are well known for their ability to degrade lignified wood cell walls through cavity (Type I; characteristic cavities in wood cell walls) and erosion (Type II; surface erosion of wood cell walls) decay (Daniel and Nilsson, 1989, 1998; Daniel, 2016) and are known to produce both extracellular cellulases and hemicellulases (Nilsson, 1974; Berg, 1978; Duncan et al., 2006) in-vitro on agarose/agar plates. Phialophora are a group of cosmopolitan anamorph fungi with worldwide distribution having been isolated from a wide range of Cu-treated wood in-service in ground contact situations (Daniel and Nilsson, 1988; Daniel, 2016).

\section{Materials and methods}

\subsection{Fungal cultures}

Phialophora malorum (strain 211-C-15-1) (M. N. Kidd \& A. Beaumont) McColloch (syn = Cadophora malorum; Harrington and McNew, 2003) was obtained from the culture collection maintained at the Department of Biomaterials and Technology/Wood Science where it is routinely grown on $2.5 \% \mathrm{w} / \mathrm{v}$ malt extract agar (MEA) at $20^{\circ} \mathrm{C}$. The strain was previously isolated from $2 \% \mathrm{w} / \mathrm{v}$ CCA treated poles (Henningsson and Nilsson, 1976). The fungus was grown in 500-mL shaked flasks (VKS Edmund Buhler horizontal rotary shaker; $80 \mathrm{rpm}$ ) containing Abram's basic salt medium $\left(\mathrm{KH}_{2} \mathrm{PO}_{4}, 0.1 \% \mathrm{w} / \mathrm{v}\right.$; $\left.\mathrm{MgSO}_{4} \cdot 7 \mathrm{H}_{2} \mathrm{O}, 0.1 \% \mathrm{w} / \mathrm{v}\right)$ amended with glucose $(2 \% \mathrm{w} / \mathrm{v})$, peptone from animal tissue (Sigma 5905) $(0.05 \% \mathrm{w} / \mathrm{v})$ and glutamic acid $(0.05 \% \mathrm{w} / \mathrm{v})$ at room temperature. Details on culturing have been described previously (Karunasekera and Daniel, 2013). Under these conditions the fungus forms mycelia pellets. For Cu-cultures, the medium was supplemented with $0.1 \% \mathrm{w} / \mathrm{v} \mathrm{CuSO}_{4}$ (Sigma). Preliminary analysis of $P$. malorum cultures were also conducted with both young (i.e. 4 days) and old cultures (i.e. 6 weeks that was used in previous experiments) to determine via electrophoresis the nature of the protein profiles. The 6 week old cultures produced very complicated and dense electrophoresis profiles where it was difficult to distinguish and characterise discrete protein bands associated with copper, while the 4 day old cultures were too early to see an effect of copper. Thus after several trials, a 10 day culture period was selected which was also within the logarimetic growth phase. A rather low copper concentration was used (i.e. $0.1 \% \mathrm{CuSO}_{4}$ ) compared with what $P$. malorum has been shown to tolerate in in-vitro liquid cultures and on Cu-agar (Daniel and Nilsson, 1988, 1989; 1998; Karunasekera and Daniel, 2013) as this concentration was shown previously to provide a stimulatory effect reflected by an increase in mycelial dry wt compared with control cultures (Karunasekera and Daniel, 2013).

\subsection{Extraction of fungal mycelia}

Numerous trials with different extraction buffers were examined. However, the buffer providing optimal protein extraction contained $200 \mathrm{mM} \mathrm{CaCl}_{2}, 10 \mathrm{mM}$ EDTA, 10\% v/v glycerol and protease inhibitors ( $2 \mathrm{mM}$ Pefabloc and $10 \mu \mathrm{g} / \mathrm{ml}$ each of aprotinin, leupeptin, pepstatin, antipain and soybean trypsin inhibitor) in $50 \mathrm{mM}$ BisTris-HCl, $\mathrm{pH} 4.5$ (after dissolution of $\mathrm{CaCl}_{2}$, glycerol and EDTA in $50 \mathrm{mM}$ BisTris- $\mathrm{HCl} \mathrm{pH}$ 6.0, the $\mathrm{pH}$ dropped to ca 3.5 ; $\mathrm{pH}$ was then adjusted to 4.5 ).

Mycelia from 10-day-old shake cultures grown in $0.1 \% \mathrm{w} / \mathrm{v} \mathrm{CuSO}_{4}$ and control cultures without copper were harvested on sintered glass (no. 2) funnel, washed $4 \mathrm{x}$ with the same volume of distilled water (ca. $20 \mathrm{~mL}$ ), drained of excess water and frozen at $-20^{\circ} \mathrm{C}$. Two $\mathrm{g}$ wet wt. mycelia for each sample was then extracted for $2 \mathrm{~h}$ at $4^{\circ} \mathrm{C}$ into $20 \mathrm{ml}$ of the extraction buffer in $50-\mathrm{ml}$ plastic vials fixed on a vertical rotator. Extracts were then separated from mycelia on a sintered glass funnel under mild vacuum and prior to ultrafiltration (UF) concentration, using a $0.45 \mu \mathrm{m}$ syringe filter holder (Minisart NML, Sartorius). Studies revealed no difference in protein profiles using either fresh or previously frozen $\left(-20^{\circ} \mathrm{C}\right)$ mycelia.

Light- and fluorescence microscopy observations (not shown) of mycelia after staining with DAPI (4'6-diamino-2-phenylindole, Sigma Aldrich) (Karunasekera and Daniel, 2013) following extraction showed hyphae with cellular content and viable nuclei proving the extraction process was mild and non-destructive (i.e. the cell membrane remained intact).

\subsection{Experimental set-up for extract concentration of copper grown and control cultures}

Extracts of $P$. malorum mycelia grown in $0.1 \% \mathrm{w} / \mathrm{v} \mathrm{CuSO}_{4}$ was concentrated on PLGC (Millipore 04310) NMWL $10 \mathrm{kDa}$ regenerated cellulose UF membranes, $Q 44.5 \mathrm{~mm}$ (Millipore) to apparent 'dryness', followed by addition of $0.6 \mathrm{ml}$ of $100 \mathrm{mM} \mathrm{NaCl}$ in $50 \mathrm{mM}$ Tris- $\mathrm{HCl} \mathrm{pH} 8$ and stirred without pressure for $10 \mathrm{~min}$. The concentrated sample was then transferred to 2-mL Eppendorf tubes and centrifuged for $10 \mathrm{~min}$ at $15000 \mathrm{~g}$ to remove any precipitates. Soluble proteins in the supernatant made up to $750 \mu \mathrm{L}$ were precipitated for $2 \mathrm{~h}$ on ice using $100 \%$ TCA $(132.4 \mu \mathrm{L})$ added slowly under vigorous mixing (resulting 15\% TCA). Precipitated proteins were subsequently pelleted by centrifugation at $15000 \mathrm{~g}$ for $15 \mathrm{~min}$. The pellet was then washed with ice-cold acetone $(2 \times 200 \mu \mathrm{L}$ ), vortexed and spun down at $10000 \mathrm{~g}$ for $10 \mathrm{~min}$ (MIKRO $22 \mathrm{R}$ table centrifuge). Extracts of $2 \mathrm{~g}$ wet wt. mycelia from control flasks without copper were prepared, concentrated and precipitated as described for copper cultures.

\subsection{SDS-PAGE}

Extracts from copper- and control cultures were dissolved in $100 \mu \mathrm{L}$ SDS sample buffer and heated for $5 \mathrm{~min}$ at $95^{\circ} \mathrm{C}$ with vortex mixing at 3 and $5 \mathrm{~min}$. Proteins were fractionated using a $10 \%$ gel at loadings of 5 , 10 and $20 \mu \mathrm{L}$ per well and detected using silver (Fig. 1). A range of protein markers $(25-110 \mathrm{kDa})$ was included as standards. SDS-PAGE gels were run $5 \mathrm{x}$ with similar results from different experiments. 


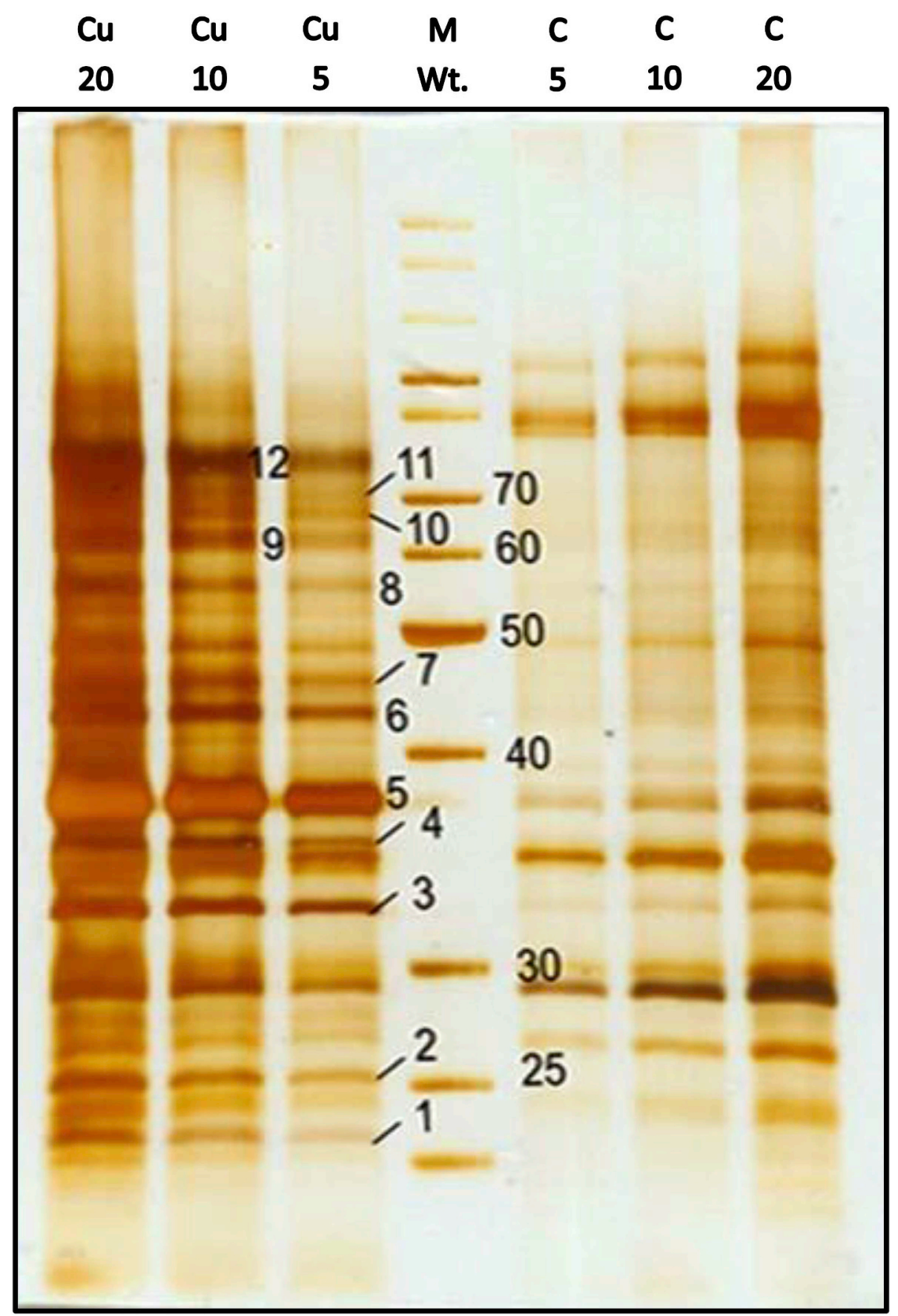

Fig. 1. SDS-PAGE of proteins extracted from the extracellular subproteome of $P$. malorum (10 day old cultures). From left to right, loading scheme was: (Cu) 20 , (Cu) 10, (Cu) $5 \mu \mathrm{L}$ of $P$. malorum Cu-sample extract and (c) 5, (c) 10, (c) $20 \mu \mathrm{L}$ control extracts. Molecular weight standards in kDa are shown in the central lane. Numbers 1-12 represent bands selected for subsequent MALDI-TOF MS/MS analysis. Comparison of the profiles shows that a number of bands present in the Cu-extract are either missing or very weak in the control extracts removed after the same growth period.

\subsection{Enzymatic digestion for MALDI-TOF MS/MS}

Silver-stained protein bands excised from gels, were cut into small pieces and washed with a freshly prepared solution of $30 \mathrm{mM}$ potassium ferricyanide and $100 \mathrm{mM}$ sodium thiosulfate (mixed in 1:1 ratio). After complete destaining, the proteins were reduced with $30 \mathrm{mM}$ TCEP in $100 \mathrm{mM}$ Tris- $\mathrm{HCl}(\mathrm{pH} 8.0)$ at $65^{\circ} \mathrm{C}$ for $30 \mathrm{~min}$ and alkylated by $30 \mathrm{mM}$ iodacetamide in $100 \mathrm{mM}$ Tris- $\mathrm{HCl}(\mathrm{pH} 8.0)$ for $60 \mathrm{~min}$ in the dark. The gel was washed further with water, shrunk by dehydration in acetonitrile (MeCN) and re-swelled in water. The supernatant was removed and the gel partly dried in a SpeedVac concentrator. The gel pieces were then incubated overnight at $37^{\circ} \mathrm{C}$ in a cleavage buffer containing
$25 \mathrm{mM}$ 4-ethylmorpholine acetate, $5 \% \mathrm{MeCN}$ and trypsin (100 ng; Promega). Tryptic digestion was performed in a mixture of $\mathrm{H}_{2}{ }^{16} \mathrm{O}$ and isotopic $\mathrm{H}_{2}{ }^{18} \mathrm{O}$ (1:1) leading to incorporation of ${ }^{16} \mathrm{OH}$ as well as ${ }^{18} \mathrm{OH}$ at the C-terminus of each newly formed peptide. In MS/MS analysis of such ${ }^{16} \mathrm{O} /{ }^{18} \mathrm{O}$ labelled peptides, $\mathrm{N}$-terminal b-ions appeared with their normal isotopic pattern, whereas C-terminal y-ions had a typical profile of doublets differing by $2 \mathrm{Da}$. This feature clearly distinguished b- and $\mathrm{y}$-ions and thus facilitated the assignment of peptide sequences. The resulting peptides were extracted to $40 \%$ in $\mathrm{MeCN} / 0.1 \%$ TFA. An aqueous $50 \% \mathrm{MeCN} / 0.1 \%$ TFA solution of $\alpha$-cyano-4-hydroxycinnamic acid $(5 \mathrm{mg} / \mathrm{ml}$; Sigma) was used as a MALDI matrix. One $\mu \mathrm{l}$ of the peptide mixture was deposited on the MALDI plate, allowed to air-dry 
at room temperature and overlaid with $0.4 \mu \mathrm{L}$ of the matrix.

\subsection{MALDI mass spectrometry and protein identification}

Mass spectra were measured on an Ultraflex III MALDI-TOF MS/MS instrument (Bruker Daltonics, Bremen, Germany) in the mass range of 700-4000 Da and calibrated internally using the monoisotopic [M $+\mathrm{H}]^{+}$ions of trypsin auto proteolytic fragments (842.5 and 2211.1 Da). The amino acid sequences manually derived from the acquired MS/MS spectra were searched against NCBIn__2016_06 database using the MS-BLAST program (http://genetics.bwh.harvard.edu/ msblast/) developed for short sequence tags extracted from the MS data. Because the genome of $P$. malorum is unknown, polypeptides were identified on the basis of high sequence homology with related fungal species (phylogenetic, habitat and ability to degrade natural polymers). To confirm the identity of the peptides, their exact masses were measured in MALDI mode using a SolariX XR ${ }^{\mathrm{TM}}$ FT-ICR mass spectrometer (Bruker Daltonics) with mass accuracy below $2 \mathrm{ppm}$.

\section{Results}

\subsection{General-culturing}

After 10 days growth the culture fluid of the Cu-supplemented cultures had a slight green-blue appearance, as did the filtered mycelia in comparison to controls consistent with previous studies (Daniel and Nilsson, 1988; Karunasekera et al., 2019). During protein extraction, the distinctly greenish-blue mycelia changed colour becoming more creamy-white similar to the control samples suggesting loss of $\mathrm{Cu}$ (II) ions from the fungal cell wall and extracellular slime materials.

\subsection{SDS-PAGE}

Fig. 1 shows typical protein profiles obtained with different loadings $(5-20 \mu \mathrm{L})$ of extracted extracellular proteins isolated by mild extraction of $P$. malorum mycelia after 10 days growth. Comparison of the protein profiles shows several bands present in the Cu-extracts (i.e. bands marked 1-12 between ca 25 and $110 \mathrm{kDa}$, Fig. 1) as absent or very weak in the control extracts taken after the same growth period suggesting differential expression of unique proteins or strong up-regulation of existing proteins.

\subsection{MALDI-TOF MS/MS protein identification}

Silver-stained protein bands were in-gel trypsin-digested and the peptides identified using MALDI-TOF MS/MS (Table 1). Identity of the proteins was revealed based on the high sequence homology with related species from similar phylogenetic groups and soil habitat or capability for decaying natural polymers (e.g. cellulose). Analysis of the 12 bands showed a variety of protein sequences that could be ascribed to a number of enzymes including: peptidases, proteases, pectinase/ polygalacturonase and glucosidases as well as hypothetical proteins (Tables 1 and 2). In particular, the hydrolases glucosidases, peptidases, pectinase/polygalacturonase were dominating (Fig. 1; Tables 1 and 2).

\section{Discussion}

Considerable research to clarify physiological and molecular mechanisms underlying metal tolerance by a variety of microorganisms particularly copper in fungi has been conducted (Gadd, 1993, 2007; Tang et al., 2013; Akgul and Akgul, 2018). The most effective mechanisms would be those preventing microbial cells from excessive intracellular copper uptake. With some yeasts, this has been shown through strong down-regulation of the expression of CTR1 and FRE1 genes responsible for copper intracellular transport in its reduced $\mathrm{Cu}$ (I) form and up-regulation of a Cu (I) oxidase FET3 gene to reduce copper uptake by means of Ctr1p. Other complementary mechanisms are believed to contribute to the defense strategy such as copper adsorption on the cell wall/extracellular polymeric slime (EPS) (i.e. subproteome) (Yahaya et al., 2009) and by extracellular metal complexation/chelation (El-Meleigy, 1992). In this study, we have focused on the latter possibility by assuming that the $P$. malorum cell wall components expressed under heavy copper load may represent a primary barrier against free $\mathrm{Cu}$ (II) ion diffusion (i.e. from $\mathrm{CuSO}_{4}$ ) towards the cell membrane. The hydrolytic enzymes we found (i.e. hydrolases/peptidases/glucosidases) weakly bound to the cell wall/slime and differentially over-expressed during exposure to high copper concentrations all represent a source of soluble, heavy metal complexing metabolites that can be accumulated close to the cell surface. The substrates for these enzymes are presumably the wood cell wall carbohydrate polymers and proteins of the copper-treated wood during soft rot erosion (i.e. from wood cell lumen) and cavity formation inside wood cell walls (Daniel and Nilsson, 1989; Daniel, 2016).

It is well documented that copper forms soluble complexes with amino acids (hydroxyl), carboxylic acids and carbohydrates (Beck, 2009). The mechanism of heavy metal detoxification by chelation into less toxic species with suppressed bioavailability has also been discussed. Thus, increased secretion of metal-binding metabolites such as citrate, malate and histidine could also reduce uptake of toxic free metal ions into plant cells (Rauser, 1999). For example, cells of the diatom Cylindrotheca fusiformis exposed to toxic $\mathrm{Cu}$ concentrations displayed higher carbohydrate extracellular production that paralleled the increase in Cu concentrations (Pistocchi et al., 1997). Complexation of cupric ion has also been shown to have a profound effect on ion toxicity towards bacteria. With studies on the Cu-sensitive and Cu-tolerant strains of phytopathogenic bacterium Pseudomonas syringae, $\mathrm{Cu}$ (II) toxicity was substantially reduced in the presence of a variety of organic compounds (i.e. acids, amino acids and sugars), indicating that not only strong chelating agents but also weak and moderate copper ligands can effectively antagonize copper toxicity. In this respect, the discoloration of the culture media in $P$. malorum cultures is suggestive that a similar process may be in operation. Interestingly, the complexed forms of copper were not toxic to strains of $P$. syringae (Zevenhuizen et al., 1979; Menkissoglu and Lindow, 1991; Azenha et al., 1995). Obviously, there is also a competition between soluble ligands (chelators) in solution and polymeric ligands on the hyphal cell surface, affecting the concentration of free Cu (II) (Teresa et al., 1997). In copper tolerant wood-rot fungi, a role of metal complexation/immobilization in insoluble crystals has been mostly attributed to oxalic acid secreted in elevated levels during growth under Cu-stress (Clausen et al., 2000; Clausen and Green, 2003; Green and Clausen, 2005; Jarosz-Wilkołazka and Graz, 2006; Köse and Kartal, 2010; Ohno et al., 2015; Lenz et al., 2017; Akgul and Akgul, 2018). Eight genes of the brown rot fungus Fibroporia radiculosa, up-regulated during growth of this fungus on wood treated with a copper-based preservative, had putative functions related to operation of an oxalate system (Tang et al., 2013). In contrast, $P$. malorum has not been shown to produce excess cell wall oxalate crystals attached to hyphal cell walls in copper supplemented cultures and thus the involvement of a similar oxalic acid system is unlikely (Karunasekera et al., 2019).

Our finding for the presence of pectinase/polygalacturonase proteins is also consistent with previous studies. For example, a possible role of pectinase/polygalacturonase in fungal copper tolerance mechanisms was documented in the transcriptomic study on $F$. radiculosa grown on copper-treated wood. Among several differentially regulated genes, two genes -viz 1513, GH28 polygalacturonase, and 2569, GH43 endo-1,5- $\alpha$-L-arabinanase, up-regulated at early stages of wood attack had annotations for pectin degradation (Tang et al., 2013). Pectin, an acidic polysaccharide which is largely present in plant cell walls, is a frequent target of the primary attack of wood rotting fungi. The most abundant component in pectin (ca 70\%) is polygalacturonic acid, a linear polymer of 1,4- $\alpha$-linked partially methyl-esterified d- 
Table 1

MALDI-TOF mass spectrometric identification of $P$. malorum extracellular proteins over-expressed in Cu-cultures. Table includes band number, protein name, NCBI database number, fungus species, theoretical protein molecular weight, and sequence, experimental and theoretical protonated MW and mass error of identified peptides.

\begin{tabular}{|c|c|c|c|c|c|c|c|c|}
\hline Band & Protein name & NCBI No. & Fungal organism & $\begin{array}{l}\text { Protein MW } \\
\text { theor. [kDa] }\end{array}$ & $\begin{array}{l}\text { Peptide sequence identified by MALDI-TOF } \\
\text { MS/MS analysis }\end{array}$ & $\begin{array}{l}\text { Peptide } \\
\mathrm{MH}+\text { exp. [Da] }\end{array}$ & $\begin{array}{l}\text { Peptide } \\
\mathrm{MH}+\text { theor. [Da] }\end{array}$ & $\begin{array}{l}\text { Error } \\
{[\mathrm{ppm}]}\end{array}$ \\
\hline 01 & - & & & & & & & \\
\hline \multirow[t]{2}{*}{02} & \multirow[t]{2}{*}{ Serin endopeptidase } & \multirow[t]{2}{*}{406859900} & \multirow{2}{*}{$\begin{array}{l}\text { Marssonina } \\
\text { brunnea }\end{array}$} & \multirow[t]{2}{*}{26} & YVSVPVVSR & 1005.5729 & 1005.5728 & 0.1 \\
\hline & & & & & IVGGSAAVAGQFPYQVALLR & 2017.1240 & 2017.1229 & 0.5 \\
\hline \multirow[t]{3}{*}{03} & \multirow{3}{*}{$\begin{array}{l}\text { Putative aspartic } \\
\text { protease }\end{array}$} & \multirow[t]{3}{*}{82173725} & \multirow{3}{*}{$\begin{array}{l}\text { Trichoderma } \\
\text { harzianum }\end{array}$} & \multirow[t]{3}{*}{40} & YTGTLTYFSR & 1208.5943 & 1208.5946 & 0.2 \\
\hline & & & & & FLENYYSVYDTTNSR & 1871.8455 & 1871.8446 & 0.5 \\
\hline & & & & & YYAWINDGGSSGVNTIIGQK & 2143.0483 & 2143.0455 & 1.3 \\
\hline \multirow[t]{2}{*}{04} & \multirow{2}{*}{$\begin{array}{l}\text { Hypothetical protein } \\
\text { MBM_06090 }\end{array}$} & \multirow[t]{2}{*}{406863030} & \multirow{2}{*}{$\begin{array}{l}\text { Marssonina } \\
\text { brunnea }\end{array}$} & \multirow[t]{2}{*}{29} & GVVYLQGVLR & 1103.6573 & 1103.6572 & 0.1 \\
\hline & & & & & IFLPTTPSEPSLPSVTPLPISR & 2349.3089 & 2349.3064 & 1.1 \\
\hline \multirow[t]{2}{*}{05} & \multirow{2}{*}{$\begin{array}{l}\text { Glycoside hydrolase } \\
\text { family } 28 \text { protein }\end{array}$} & \multirow[t]{2}{*}{451847121} & Bipolaris & \multirow[t]{2}{*}{37} & FFYAHSLTTSSITGLNFK & 2034.0336 & 2034.0331 & 0.2 \\
\hline & & & sorokiniana & & QTPQFFYAHSLTTSSITGLNFK & 2488.3216 & 2488.3235 & 0.8 \\
\hline \multirow[t]{2}{*}{06} & \multirow[t]{2}{*}{ Acid protease } & \multirow[t]{2}{*}{512197988} & \multirow[t]{2}{*}{ Glarea lozoyensis } & \multirow[t]{2}{*}{43} & NQIFAEATEEPGLAFAFGR & 2068.0141 & 2068.0134 & 0.3 \\
\hline & & & & & IKNQIFAEATEEPGLAFAFGR & 2309.1943 & 2309.1925 & 0.8 \\
\hline \multirow[t]{4}{*}{07} & \multirow{3}{*}{$\begin{array}{l}\text { Glycoside hydrolase } \\
\text { family } 31 \text { protein }\end{array}$} & \multirow[t]{3}{*}{972541695} & \multirow{3}{*}{$\begin{array}{l}\text { Phialocephala } \\
\text { scopiformis }\end{array}$} & $104^{\#}$ & WATLGAFSTYFR & 1419.7057 & 1419.7056 & 0.1 \\
\hline & & & & & STFSGAGSHVGHWLGDNVSSWLGYR & 2677.2549 & 2677.2542 & 0.3 \\
\hline & & & & & SPGDDVALIDLPHYQGGPDVPQR* & 2858.5610 & n.a. & n.a. \\
\hline & Pectin lyase A & 115401252 & Aspergillus terreus & 40 & GNYIYHTSGR & 1167.5542 & 1167.5542 & 0 \\
\hline 08 & - & & & & & & & \\
\hline 09 & Glycoside hydrolase & 972541695 & Phialocephala & $104^{\&}$ & YTASPFSFSITR & 1376.6848 & 1376.6845 & 0.2 \\
\hline & family 31 protein & & scopiformis & & IQDAADLVYQLPASVLPR & 1969.0769 & 1969.0753 & 0.8 \\
\hline & & & & & IQDAADLVYQLPASVLPRPK & 2194.2237 & 2194.2230 & 0.3 \\
\hline & & & & & QIVMVDPAVAYQPYPPYQR & 2235.1284 & 2235.1267 & 0.8 \\
\hline 10 & Tripeptidyl- & 406863634 & Marssonina & $81^{\#}$ & VCNGFAQLGAR & 1192.5897 & 1192.5892 & 0.4 \\
\hline & peptidase 1 & & brunnea & & ADGTIPWPYPGIHEAR & 1779.8824 & 1779.8813 & 0.6 \\
\hline & precursor & & & & NQIGFNNFLGELPIRPDTK & 2173.1406 & 2173.1400 & 0.3 \\
\hline 11 & Tripeptidyl- & 406863634 & Marssonina & $81^{\#}$ & GLFNPEGR & 889.4521 & 889.4526 & 0.6 \\
\hline & peptidase 1 & & brunnea & & VCNGFAQLGAR & 1192.5888 & 1192.5892 & 0.3 \\
\hline & precursor & & & & FLASFPPSCPYVTAVGATQGFEPETSAAR & 3058.4627 & 3058.4615 & 0.4 \\
\hline 12 & Hypothetical protein & 406861275 & Marssonina & 73 & SGLGFLNPVLYR & 1335.7432 & 1335.7420 & 0.9 \\
\hline & MBM_07560 & & brunnea & & VISASYGQAEADLPAPYVR & 2007.0192 & 2007.0182 & 0.5 \\
\hline & Subtilisin-like & 512200580 & Glarea lozoyensis & 72 & NQCGLYKPTR & 1236.6150 & 1236.6154 & 0.3 \\
\hline & protein & & & & VISVSYGVSEYDAPLSYTK & 2078.0325 & 2078.0328 & 0.1 \\
\hline & & & & & AHDPGLPYYVANDAATNIGANGGLYNR & 2804.3409 & 2804.3387 & 0.8 \\
\hline
\end{tabular}

\# Identified peptides match to the C-terminal part of the protein.

${ }^{\&}$ Identified peptides match to the $\mathrm{N}$-terminal part of the protein.

* Only partial peptide sequence was identified.

$\$$ Measured on MALDI-FTICR mass spectrometer.

n.a.; not applied.

galacturonate units. Free carboxylic groups of pectins are able to bind strongly polyvalent metal cations including $\mathrm{Cu}$ (II) (Cataldo et al., 2012). Accordingly, a substantial portion of the $\mathrm{Cu}$ that accumulated into cell walls of the Cu-treated Lygodium japonicum (fern) and Scopelophila cataractae (moss) cells was tightly bound to the homogalacturonan of cell wall pectin (Konno et al., 2005; Konno and Nakashima, 2010).

Possible modes of complexation of $\mathrm{Cu}$ (II) cations by D-galacturonic acid (GalA) in solution or in solid state have also been widely investigated and several ways of coordination binding have been suggested (Debongnie et al., 1987; Synytsya et al., 2004; Shestavin et al., 2003). Due to the $\mathrm{COOH}$ group, the complex-forming ability of the sugar acid is known to be highly enhanced relative to neutral sugars, even in acidic solution (pH > 3) (Shestavin et al., 2003; Gyurcsik and Nagy, 2000). Stronger coordination bonds were formed with monomeric galacturonic acid compared to its polymeric form in pectin

Table 2

Extracted extracellular proteins, putative metabolic activities and fungal specie assignment.

\begin{tabular}{|c|c|c|}
\hline Protein name & Putative activity (Metabolic process) & Phylogenetic assignment of peptides (Fungal species) \\
\hline 1. & No protein identified & \\
\hline 2. Serin endopeptidase & Trypsin-like serine protease & Marssonina brunnea \\
\hline 3. Putative aspartic protease & Pepsin-like aspartic protease & Trichoderma harzianum \\
\hline 4. Hypothetical protein MBM_06090 & & Marssonina brunnea \\
\hline 5. Glycoside hydrolase family 28 protein & Polygalacturonase & Bipolaris sorokiniana \\
\hline 6. Acid protease & Pepsin-like aspartic protease & Glarea lozoyensis \\
\hline 7. Glycoside hydrolase family 31 protein & Alpha/beta glucosidase & Phialocephala scopiformis \\
\hline Pectin lyase A & Pectinase & Aspergillus terreus \\
\hline 8. & No protein identified & \\
\hline 9. Glycoside hydrolase family 31 protein & Alpha/beta glucosidase & Phialocephala scopiformis \\
\hline 10. Tripeptidyl-peptidase 1 precursor & Peptidase S53 & Marssonina brunnea \\
\hline 11.Tripeptidyl-peptidase 1 precursor & Peptidase S53 & Marssonina brunnea \\
\hline 12. Hypothetical protein MBM_07560 & Peptidase S53 & Marssonina brunnea \\
\hline Subtilisin-like protein & Peptidase S53 & Glarea lozoyensis \\
\hline
\end{tabular}


(Debongnie et al., 1987). Thus, pectinase activity elicited at the hyphal surface during soft rot attack of Cu-treated wood may provide $P$. malorum not only with a nutrient sugar but also with an efficient copper chelator. Interactions between metal ions and other carbohydrates have also been shown to play a role in toxic metal metabolism. For example, two components demonstrated to bind $\mathrm{Ni}^{2+}$ in human kidney were identified as small acidic oligosaccharides and a $\sim 3.5 \mathrm{kDa}$ acidic peptide (Predki et al., 1992). Synthesis of sugar acids (formic, malic, oxalic) in liquid media by the white rot fungus Trametes versicolor in the presence of CuHDO active ingredients copper oxide, boric acid and $\mathrm{Cu}$ HDO [bis-(N-cyclohexyl-diazeniumdioxy) copper] have also been reported (Betlej and Graz, 2006).

Over-expression of glucosidases (Fig. 1; Table 2) identified in our $P$. malorum cell wall proteomic study may also contribute to $P$. malorum copper resistance in a similar way as pectinase, although, probably to a lesser extent due to weaker chelation. In this context, neutral reducing monosaccharides were also recognized in solution to undergo extensive coordination with polyvalent metal cations such as Cu (II) (González et al., 2010; Pal and Paul, 2008). While there is vast literature focused on the structural chemistry of stable carbohydrate-metal ion coordination complexes formed under strongly binding conditions in alkaline media, the chemistry of metal-non-deprotonated sugar complexes is still a challenging field. This is due to the relatively low stability of the complexes in neutral or acidic aqueous solutions, and the fact that in solutions of sugars, the species are in anomeric and conformational equilibrium, and the isomers interact in different ways with metal ions. There is, nevertheless, strong evidence that these ligands (sugars in pyranose or furanose form) produce 1:1 complexes with metal cations in hydrophilic solvents where coordination of oxygen atoms of non-deprotonated $\mathrm{OH}$ groups takes place (Gyurcsik and Nagy, 2000). The coordination behavior between metal and sugar $\mathrm{OH}$ groups is therefore important not only to understand with respect to the physiological role of metal ions (Allscher et al., 2008) but also complexation as is the case with $P$. malorum. Strong metal chelating power of amino acids and peptides, produced through the $\mathrm{Cu}$-affected $P$. malorum peptidases/proteases/hydrolases we have detected is also well known (Ytreberg et al., 2011).

In summary, the concentration of metabolites released in close vicinity of the hyphal surface (i.e. during soft rot erosion and cavity formation) by weakly bound hydrolytic enzymes overexpressed in response to copper stress may be high enough to effectively reduce the level of free/non-chelated $\mathrm{Cu}$ (II) ions available to the native 'biotic' ligand such as Fre1p involved in copper intracellular transport. The resulting reduced intracellular copper accumulation in combination with presumed internal mechanisms of the metal sequestration, extrusion, and detoxification may therefore confer high resistance to the environmental copper exposure to/on $P$. malorum hyphae.

\section{Conclusions}

A novel approach has been developed for characterizing extracellular proteins/peptides present in the cell wall/extracellular slime subproteome (i.e. lying outside the cell membrane) of the Cu-tolerant soft rot fungus $P$. malorum. Twelve proteins/peptide fractions were either unique or over expressed in copper cultures. The subproteome location of the proteins was consistent with a role in copper tolerance/ $\mathrm{Cu}$-detoxification by binding $\mathrm{Cu}$ ions extracellularly. Several of the proteins isolated (e.g. hydrolases) are also implicated in wood cell wall attack and likely operate with organic acids to bind excess $\mathrm{Cu}$ ions released during decay. The subproteome approach developed provides a novel way to extract and profile extracellular proteins from fungal hyphae that may be applied in other studies.

\section{Acknowledgments}

This study was supported by The Swedish Research Council for
Environment, Agricultural Sciences and Spatial Planning (FORMAS) (Grants: 2011-416; 2011-6383-19675 and 2008-1399). Profs A. Käärik, T. Nilsson and B. Henningsson are acknowledged for the original isolation of $P$. malorum.

\section{Appendix A. Supplementary data}

Supplementary data to this article can be found online at https:// doi.org/10.1016/j.ibiod.2019.104769.

\section{References}

Allscher, T., Klüffers, P., Mayer, P., 2008. Carbohydrate-metal complexes: structural chemistry of stable solution species. In: Tatsuta, K., Thiem, J. (Eds.), Glycoscience Chemistry and Chemical Biology, Fraser-Reid B. Springer-Verlag Berlin Heidelberg, pp. 1077-11392008.

Akgul, A., Akgul, A., 2018. Mycoremediation of copper: exploring the metal tolerance of brown rot fungi. Bioresources 13 (3), 7155-7171.

Azenha, M., Vasconcelos, M.T., Cabral, J.P.S., 1995. Organic ligands reduce copper toxicity in Pseudomonas syringae. Environ. Toxicol. Chem. 14, 369-373.

Beck, W., 2009. Metal complexes of biologically important ligands. Metal ions and metal complexes as protective groups of amino acids and peptides - reactions at coordinated amino acids. Z. Naturforsch. 64b, 1221-1245.

Berg, B., 1978. Cellulose degradation and cellulase formation by Phialophora malorum. Arch. Microbiol. 118, 61-65.

Betlej, I., Graz, M., 2006. The identification or organic acids in Trametes versicolor cultures, growing on a media with CuHDO complex. Folia For. Pol.sera B, Zeszyt 37, 3-7.

Cataldo, S., Gianguzza, A., Pettignano, A., Piazzese, D., Sammartano, S., 2012. Complex Formation of copper (II) and cadmium (II) with pectin and polygalacturonic acid in aqueous solution. An ISE- $\mathrm{H}^{+}$and ISE-Me ${ }^{2+}$ electrochemical study. Int. J. Electrochem. Sci. 7, 6722-6737.

Clausen, C.A., Green, F., Woodward, B.M., Evans, J.W., DeGroot, R.C., 2000. Correlation between oxalic acid production and copper tolerance in Wolfiporia cocos. Int. Biodeterior. Biodegrad. 46, 69-76.

Clausen, C.A., Green, F., 2003. Oxalic acid overproduction by copper tolerant brown-rot basidiomycetes on southern yellow pine treated with copper-based preservatives. Int. Biodeterior. Biodegrad. 51, 139-144.

Daniel, G., 2016. Fungal degradation of wood cell walls. In: Kim, Y.S., Funada, R., Singh, A.P. (Eds.), Secondary Xylem Biology. Elsevier Academic Press, Amsterdam978-0-12802185-9, Ch. 8., pp.131-167.. https://doi.org/10.1016/B978-0-12-802185-9. 00008-5.

Daniel, G., Nilsson, T., 1988. Studies on preservative tolerant Phialophora species. Int. Biodeterior. 24, 327-335.

Daniel, G., Nilsson, T., 1989. Interactions between soft rot fungi and CCA preservatives in Betula verrucosa. J. Inst. Wood Sci. 11, 162-171.

Daniel, G., Nilsson, T., 1998. Developments in the study of soft rot and bacterial decay. In: Bruce, A., Palfreyman, J.W. (Eds.), Forest Products Biotechnology. CRC Press, London, pp. 37-62.

Debongnie, P., Mestdagh, M., Rinaudo, M., 1987. An E.P.R. and potentiometric study of the complexation of copper ions by galacturonic acid and galacturonates. Carbohydr. Res. 170, 137-149.

Duncan, S.M., Farrell, R.L., Thwaites, J.M., Held, B.W., Arenz, B.E., Jurgens, J.A., Blanchette, R.A., 2006. Endoglucanase-producing fungi isolated from Cape Evans historic expedition hut on Ross Island, Antarctica. Environ. Microbiol. 8 (7), 1212-1219.

El-Meleigy, M.A., 1992. Copper organo-chelators in Aspergillus fumigatus and Penicillium chrysogenum. Biol. Trace Elem. Res. 34 (2), 177-183.

Gadd, G.M., 1993. Interactions of fungi with toxic metals. New Phytol. 124, 25-60.

Gadd, G.M., 2007. Geomycology: biogeochemical transformations of rocks, minerals, metals, and radionuclides by fungi, bioweathering and bioremediation. Mycol. Res. 11, 3-49.

González, A.G., Shirokova, L.S., Pokrovsky, O.S., Emnova, E.E., Martínez, R.E., SantanaCasiano, J.M., González-Dávila, M., Pokrovski, G.S., 2010. Adsorption of copper on Pseudomonas aureofaciens: protective role of surface exopolysaccharides. J. Colloid Interface Sci. 350, 305-314.

Green, F., Clausen, C.A., 2003. Copper tolerance of brown-rot fungi: time course of oxalic acid production. Int. Biodeterior. Biodegrad. 51, 145-149.

Green III, F., Clausen, C.A., 2005. Copper tolerance of brown-rot fungi: oxalic acid production in southern pine treated with arsenic-free preservatives. Int. Biodeterior. Biodegrad. 56, 75-79.

Gyurcsik, B., Nagy, L., 2000. Carbohydrates as ligands: coordination equilibria and structure of the metal complexes. Coord. Chem. Rev. 203, 81-149.

Hall, J.L., 2002. Cellular mechanisms for heavy metal detoxification and tolerance. J. Exp. Bot. 53 (366), 1-11.

Harrington, T.C., McNew, D.L., 2003. Phylogenetic analysis places the Phialophora-like anamorph genus Cadophora in the Helotiales. Mycotaxon 87, 141-151.

Henningsson, B., Nilsson, T., 1976. Some aspects on microflora and the decomposition of preservative-treated wood in ground contact. Mater. Org. (Berl.) 3, 307-318.

Humar, M., Thaler, N., 2017. Performance of copper treated ultility poles and posts used in service for several years. Int. Biodeterior. Biodegrad. 116, 219-226.

Ito, H., Inouhe, M., Tohoyama, H., Joho, M., 2007. Copper extrusion after accumulation during growth of copper-tolerant yeast Yarrowia lipolytica. Z. Naturforschung 62, 
$77-82$.

Jacobs, K., Buschelberger, F., Plaschkies, K., 2016. Virulence of wood decay fungi in biological tests for the determination of the efficacy of wood preservatives and the durability of wood and wood based materials. Dtsch.Holzschutztagung 144-158.

Jarosz-Wilkołazka, A., Graz, M., 2006. Organic acids production by white rot basidiomycetes in the presence of metallic oxides. Can. J. Microbiol. 52, 779-785.

Karunasekera, H., Daniel, G., 2013. Molecular identification and phylogenic analysis by sequencing the rDNA of copper-tolerant soft-rot Phialophora spp. Int. Biodeterior. Biodegrad. 82, 45-52.

Karunasekera, H., Terziev, N., Daniel, G., 2017. Does copper tolerance provide a competitive advantage for degrading copper treated wood by soft rot fungi? Int. Biodeterior. Biodegrad. 117, 105-114.

Karunasekera, H., Pettersson, J., Mi, J., Bergquist, J., Daniel, G., 2019. Copper tolerance of the soft-rot fungus Phialophora malorum grown in-vitro revealed by microscopy and global protein expression. Int. Biodeterior. Biodegrad. 137, 147-152.

Konno, H., Nakato, T., Nakashima, S., Katoh, K., 2005. Lygonium japonicum fern accumulates copper in the cell wall pectin. J. Exp. Bot. 56, 1923-1931.

Konno, H., Nakashima, S., 2010. Metal-tolerant moss Scopelophila cataractae accumulates copper in the cell wall pectin of the protonema. J. Plant Physiol. 167, 358-364.

Köse, C., Kartal, S.N., 2010. Tolerance of brown-rot and dry-rot fungi to CCA and ACQ wood preservatives. Turk. J. Agric. For. 34, 181-190.

Lenz, C., Eckhard, M., Möller, R., Lautner, S., 2017. Microscopic investigations concerning in-situ oxalate formation by the brown-rot fungus Poria placenta. Drewno 60 (199), 5-19.

Mantanis, G., Terzi, E., Kartal, S.N., Papadopoulos, A.N., 2014. Evaluation of mold, decay and termite resistance of pine wood treated with zinc-and copper-based nanocompounds. Int. Biodeterior. Biodegrad. 90, 140-144.

Menkissoglu, O., Lindow, S.E., 1991. Relationship of free ionic copper and toxicity to bacteria in solutions of organic compounds. Phytopathology 81, 1258-1263.

Nilsson, T., 1974. Microscopic studies on the degradation of cellophane and various cellulosic fibres by wood-attacking micro fungi. Stud. For. Suec. 117, 1-37.

Ohno, K.M., Clausen, C.A., Green, F., Diehl, S.V., 2015. Insights into the mechanism of copper-tolerance in Fibroporia radiculosa: the biosynthesis of oxalate. Int. Biodeterior. Biodegrad. 105, 90-96. https://doi.org/10.1016/j.ibiod.205.08.016.

Pal, A., Paul, A.K., 2008. Microbial extracellular polymeric substances: central elements in heavy metal bioremediation. Indian J. Microbiol. 48, 49-64.

Pearce, D.A., Sherman, F., 1999. Toxicity of copper, cobalt, and nickel salts is dependent on histidine metabolism in the yeast Saccharomyces cerevisiae. J. Bacteriol. 181,
4774-4779.

Pistocchi, R., Guerrini, F., Balboni, V., Boni, L., 1997. Copper toxicity and carbohydrate production in the microalgae Cylindrotheca fusiformis and Gymnodinium sp. Eur. J. Phycol. 32, 125-132.

Predki, P.F., Whitfield, D.M., Sarkar, B., 1992. Characterization and cellular distribution of acidic peptide and oligosaccharide metal-binding compounds from kidneys. Biochem. J. 281, 835-841.

Rauser, W.E., 1999. Structure and function of metal chelators produced by plants: the case of organic acids, amino acids, phytin, and metallothioneins. Cell Biochem. Biophys. 31, 19-48.

Schwartz, J.A., Olarte, K.T., Michalek, J.L., Gurjinder, S., Jandu, G.S., Sarah, L.J., Michel, S.L.J., Bruno, V.M., 2013. Regulation of copper toxicity by Candida albicans GPA2. Eukaryot. Cell 12, 954-961.

Shestavin, A.I., Bolotin, S.N., Volynkin, V.A., Panyushkin, V.T., 2003. ESR and NMR study of galacturonic acids complex formation in solution. J. Mol. Liq. 107 (1-3), 69-75.

Synytsya, A., Urbanová, M., Setnička, V., Tkadlecová, M., Havlíček, J., Raich, I., Matějka, P., Synytsya, A., Čopíková, J., Volka, K., 2004. The complexation of metal cations by D-galacturonic acid: a spectroscopic study. Carbohydr. Res. 339, 2391-2405.

Tang, J.D., Parker, L.A., Perkins, A.D., Sonstegard, T.S., Schroeder, S.G., Nicholasn, D.D., Diehl, S.V., 2013. Gene expression analysis of copper tolerance and wood decay in the brown rot fungus Fibroporia radiculosa. Appl. Environ. Microbiol. 79, 1523-1533.

Teresa, M., Vasconcelos, S.D., Azenha, M.A.O., Cabral, J.P.S., 1997. Comparison of availability of copper (II) complexes with organic ligands to bacterial cells and to chitin. Environ. Toxicol. Chem. 16, 2029-2039.

Weissman, Z., Berdicevsky, I., Cavari, B.-Z., Kornitzer, D., 2000. The high copper tolerance of Candida albicans is mediated by a P-type ATPase. Proc. Natl. Acad. Sci. USA 97, 3520-3525.

Yahaya, Y.A., Don, M.M., Bhatia, S., 2009. Biosorption of copper (II) onto immobilized cells of Pycnoporus sanguineus from aqueous solution: equilibrium and kinetic studies. J. Hazard Mater. 161, 189-195.

Ytreberg, E., Karlsson, J., Hoppe, S., Eklund, B., Ndungu, K., 2011. Effect of organic complexation on copper accumulation and toxicity to the estuarine red macroalga Ceramium tenuicorne: a test of the free ion activity model. Environ. Sci. Technol. 45, 3145-3153.

Zevenhuizen, L.P., Dolfing, J., Eshuis, E.J., Scholten-Koerselman, I.J., 1979. Inhibitory effects of copper on bacteria related to the free ion concentration. Microb. Ecol. 5 , 139-164. 